\title{
Utilization of RFID Technology in the Employee Mobility System of the Inspectorate Office of Merauke Regency
}

\author{
Nasra Pratama Putra ${ }^{*}$, Stanly Hence Dolfi Loppies, Titi Nalurita Sayukti \\ Department of Information System, Faculty of Engineering, Universitas Musamus, Merauke 99600, Indonesia
}

\begin{abstract}
The Inspectorate of Merauke Regency has a role as an internal supervisory agency for the implementation of government in Merauke Regency. Mobility in the office has not been supported by an entry and exit permit book for employees during working hours. The impact is a lack of employee attendance information. In addition, the process of calculating the percentage of active working time also experiences problems because it is done conventionally. To solve this problem, an employee mobility system was designed in the office by utilizing Radio Frequency Identification (RFID) technology. The system was built using the prototyping method. The design of mobility devices using a limited microcontroller in the form of a prototype. Presentation of data and information from the prototype recording is displayed on a website. The website is built using PHP and javascript programming languages. The results of the study led to a new innovation in monitoring the attendance of employees at the office during working hours by the Receptionist Department. The results of this study are also able to present the calculation of earning an allowance called Tunjangan Khusus Pengawasan Daerah (TKPD) for employees in the form of a percentage of mobility activity during active working hours.
\end{abstract}

Keywords: Mobility, RFID, ESP8266, Website, TKPD

\section{Introduction}

An institution with the authority to carry out the internal supervisory function is known as the Regional Inspectorate. One of its roles is as an internal supervisory apparatus. So that the Regional Inspectorate is a busy office, especially in terms of guest visits. Frequent guest visits occur because the Regional Inspectorate is an office that serves work program consultations, financial reports, appeals of data updating results and so on. For the sake of smooth working and consultation processes, the Regional Inspectorate applies regulations to its offices. These rules are used to support and maintain employee mobility during working hours. The basis for this rule is used to calculate the earning of the allowance known as Tunjangan Khusus Pengawasan Daerah (TKPD).

Employee mobility is analogous to the process of employee activity in their work environment [1]. Can be carried out according to provisions such as after a morning absence until the afternoon absent time. This was done in order to meet the standard TKPD value per day, which was $100 \%$. In detail, morning absences accounted for $25 \%$ of active. Afternoon absences counted $25 \%$ active. The remaining $50 \%$ is obtained from the total number of employee hours worked in full while in the office. However, to measure the achievement of this $50 \%$ value, the office has not been supported by the existence of an entry and exit permit book. So that it has an impact on the results of the calculation of the percentage of TKPD earnings by the General Administration and Finance Section. In addition to these problems, if there is a guest visit, the Reception will not be able to quickly find out the presence of the employee who will be met by the guest. Problems that occur can of course be resolved if there is a system that controls employee mobility during working hours. One of them is by applying contactless technology such as Radio Frequency Identification (RFID).

Inspectorate office layout which has a special door for the entry and exit of employees can be an advantage. This door is distinguished by the entrance for guests. Where RFID technology will become a module to identify employees who will leave or return to the office during active working hours [2]. Recording of employees' active working hours starts at 8 am by identifying the rfid card on the outside of the office entrance. If the employee's data is read by a reader, the door will open and the employee can be allowed to enter the office. The identification result data will be sent directly from the reader to the database server. Meanwhile, the information will be accessible by the reception desk and the General Administration and Finance Section.

\footnotetext{
* Corresponding author : nasrapratama@unmus.ac.id
} 
During working hours, if the employee gives permission in terms of participating in outdoor activities, it is mandatory to identify the RFID card on the inside of the office entrance. The difference between the time leaving and the time returning will be calculated by the system as a reduction in the employee's active working time. So that the Office of General Administration and Finance will no longer have difficulties in calculating the active working hours of each employee. In addition, this also makes it easier for the reception of the guests if the visit process occurs. Where when there are guests who are looking for one of the employees, the Reception Department no longer needs to look for the employee in the room. The system will immediately automatically notify the employee's latest condition, whether or not he is in the office.

\section{Theoretical Review}

\subsection{Mobility System}

The system has the meaning as a group of elements that are organized, interact with each other and are integrated to achieve an organizational or company goal. The presence of a system can help an organization / company to create a competitive advantage [3]. These elements can be described in terms of the basic characteristics of a system, which are as follows:
a. Input
b. Process
c. Output
d. Components
e. Boundary
f. Environtment

In addition to the basic concept of information systems, the concept of mobility refers to the Latin meaning of social mobility, namely Mobilis. In a sense easy to move, a lot of motion or move. So that the word mobility system can be analogized as an integrated system to monitor the movement of a person or group of people in the social environment of society.

\subsection{Radio Frequency Identification (RFID)}

This technology based on radio waves is called Radio Frequency Identification (RFID). RFID is able to identify objects without the need for direct or wireless contact using a device called a tag or transponder. These wireless applications are widely used for traceability, logistics, and access control [4].

Table 1. RFID Transponder Characteristics

\begin{tabular}{|c|c|c|c|}
\hline Characteristics & $\begin{array}{c}\text { Passive } \\
\text { Tag }\end{array}$ & $\begin{array}{c}\text { Semipasif } \\
\text { Tag }\end{array}$ & $\begin{array}{c}\text { Active } \\
\text { Tag }\end{array}$ \\
\hline Power supply & $\begin{array}{c}\text { External } \\
\text { (from } \\
\text { reader) }\end{array}$ & $\begin{array}{c}\text { Internal } \\
\text { Battery }\end{array}$ & $\begin{array}{c}\text { Internal } \\
\text { Battery }\end{array}$ \\
\hline Memory Type & Read-only & Read-write & $\begin{array}{c}\text { Read- } \\
\text { write }\end{array}$ \\
\hline Read range & \pm 20 feet & \pm 100 feet & $\begin{array}{c} \pm 750 \\
\text { feet }\end{array}$ \\
\hline Tag age & $\begin{array}{c}\text { Reached } \\
20 \text { years }\end{array}$ & 2 to 7 years & $\begin{array}{c}5 \text { to } 10 \\
\text { years }\end{array}$ \\
\hline
\end{tabular}

RFID tag card or so-called transponder is a device that functions to store information for object identification. The RFID tag card itself consists of three types of tags, namely as shown in Table 1.

The Mifare RC-522 type RFID reader has a Readwrite memory type, and is capable of working with a frequency range of $13.56 \mathrm{MHz}$. So that it has a reading distance of up to \pm 3 feet. The type of RFID tag or transponder that is compatible with this module is the passive tag type. Figure 1 shows a display of the RFID reader type RC-522.

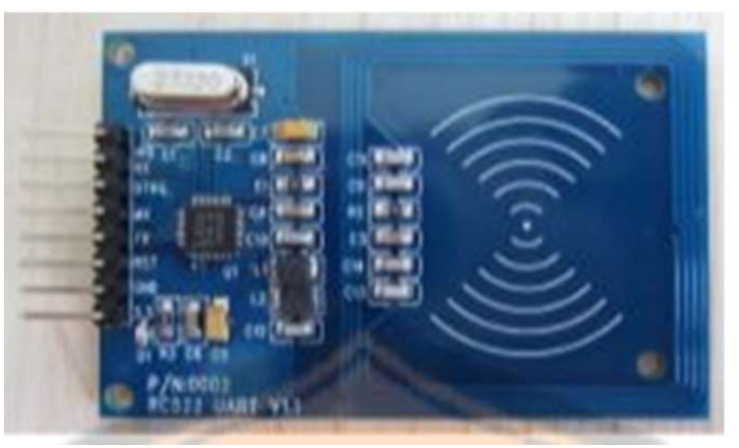

Fig. 1. Display of the RC-522 RFID Reader.

\subsection{NodeMCU ESP8266}

Data communication using wireless media can use the NodeMCU ESP8266 device. This device allows sensor operation at low cost and low power consumption. ESP8266 is widely used in various application areas such as ecosystem monitoring, object detection and monitoring and smart cities, etc [5]. In detail, the display of NodeMCU ESP8266 can be seen in Figure 2.

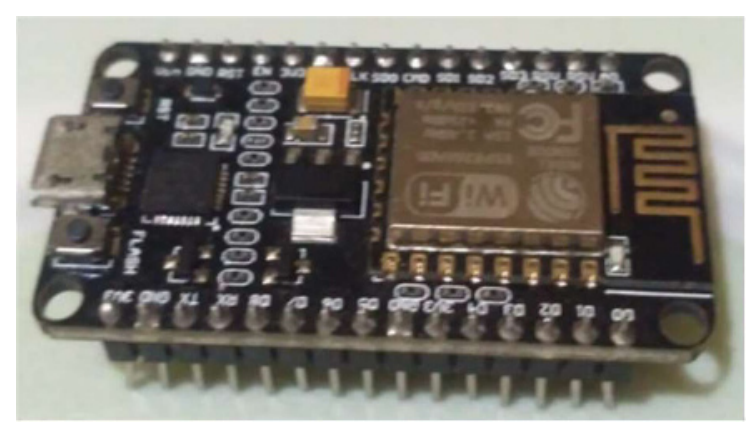

Fig. 2. Display of NodeMCU ESP8266.

This device also supports programming via the Arduino IDE for writing programs, compiling into binary code and uploading to ESP8266 memory.

\subsection{Solenoid Door lock}

Solenoid door lock is a special electronic device that is generally applied to automatic door locks. Solenoid will work if given a voltage of 12 volts [6]. The presence of a circular wire in the solenoid iron core, results in when an electric current is flowed a magnetic field occurs which then creates energy to attract the iron core inside. 
Conversely, when there is no electric current, the magnetic field will disappear along with the energy used to attract iron. Thus causing the position of the iron core to return to its original position. This is widely used for the development of automatic door locks. Figure 3 shows a display of the door lock solenoid.

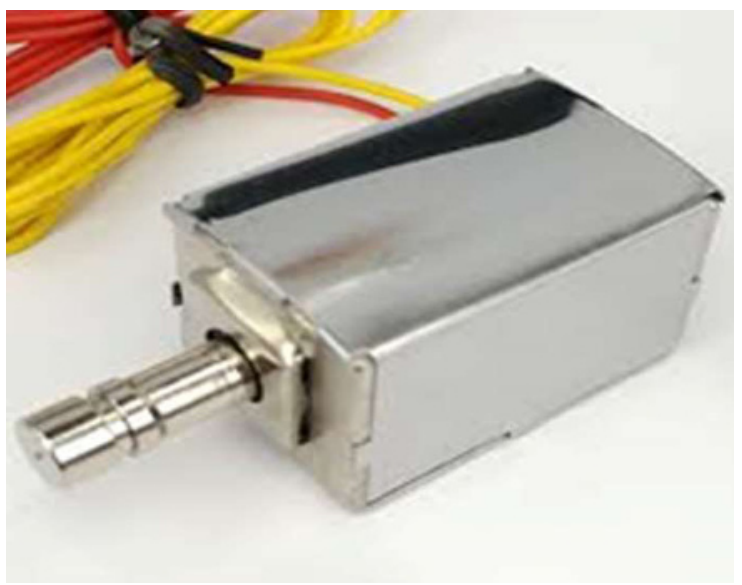

Fig. 3. Display of Solenoid Door Lock.

\subsection{Hypertext Prepocessor (PHP)}

Hypertext Prepocessor or PHP is used as a programming language for dynamic web creation, which server side scripting integrates with Hypertext Markup Language (HTML). HTML itself is a markup language or a marking of text documents to determine the format or style of text used in the creation of a web page. Its open source nature means this software can be obtained for free or for free and is suitable for use in all types of operating system platforms [7].

\subsection{JavaScript}

A collection of scripts that run on an HTML document is known as JavaScript. Is a programming language used to provide additional capabilities in HTML[8]. This, allows execution of commands by the user variable. JavaScript is very sensitive to variable naming using lowercase and uppercase letters. This makes JavaScript known as case sensitive.

\section{Methodology and System Design}

\subsection{Prototype Method}

In developing this employee mobility system, the author uses the prototype method. Where this method prioritizes the stages of communication, manufacture and testing of the system $[9,10]$. The steps are as follows:

a. Collection of needs

The data and information needed in building this system are carried out using the literature study method, which uses files, archives, and reports that are relevant to the topics raised b. Building prototype

The prototype is built by designing a temporary door model for presenting general system information to users through making system architecture diagrams

c. Prototype evaluation

The assessment is carried out on the prototype that has been built, whether it is in accordance with the needs and desires of the user or not. If so, then the next step is to code the system. However, if not, then steps $\mathrm{a}, \mathrm{b}$ and $\mathrm{c}$ are revised.

d. Coding system

Coding is done to translate the prototype design results into the PHP and JavaScript programming languages.

e. Testing the system

Testing is carried out based on two stages of testing, namely, testing the results of the prototype design and testing the black box of the website application, to test its functionality in presenting and processing data into the information needed.

f. System evaluation

Evaluation is carried out by users, namely the Reception and Public Administration and Finance to see whether the system meets the needs and desires of the user.

g. System implementation System implementation is carried out when the design results are as needed and ready for use:

\subsection{System Analyst Design}

In the following architecture diagram shows the prototype work process starting from data identification to providing information to users. There are several stages, namely:

a. The equipment will be powered on using an external power supply such as an adapter.

b. The process of reading the UID tag by the Mifare $\mathrm{RC}-522$ reader.

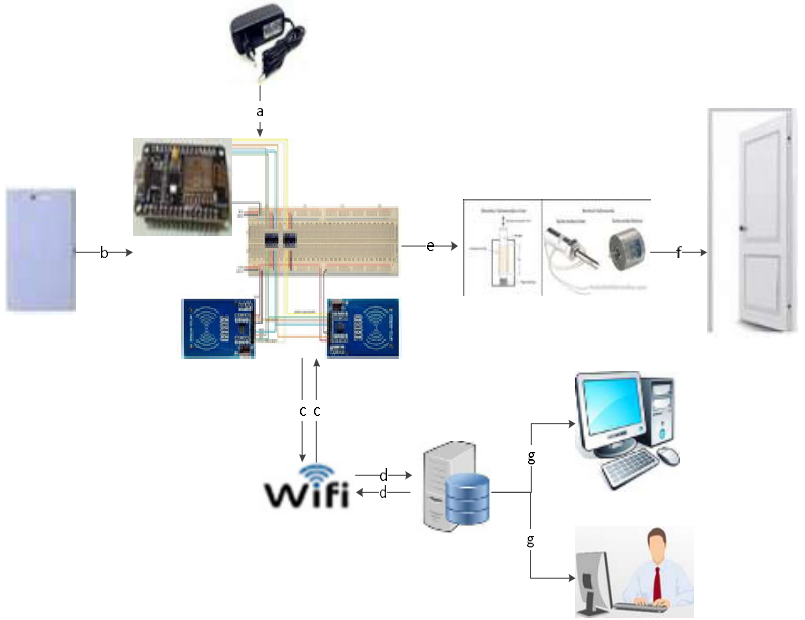

Fig. 4. Device Architecture

c. The UID tag data that is successfully read by the Mifare RC-522 reader is sent via the ESP8266 NodeMCU module to the server. 
d. The data sent is then compared with the UID tag data that has been registered in the database.

e. If the ID tag data is valid or appropriate, the microcontroller device will send a command by providing a power supply of $12 \mathrm{~V}$ to the solenoid to unlock the door.

f. After the door is successfully opened and the employee can enter the room or leave the room. then the system automatically records his presence.

g. From reading the Mifare RC-522, the employee attendance data is obtained which is then presented in the form of a website. Where the information can be accessed by the Reception and Public Administration and Finance as needed. In detail, the design can be seen in Figure 4.

\section{Results and Discussion}

\subsection{Implementation results}

Hardware or employee mobility system prototype based on Radio Frequency Identification (RFID) technology and the resulting website application is in the form of a small-scale three-dimensional imitation or commonly known as a mockup. In detail, the prototype architecture can be seen in Figure 5.
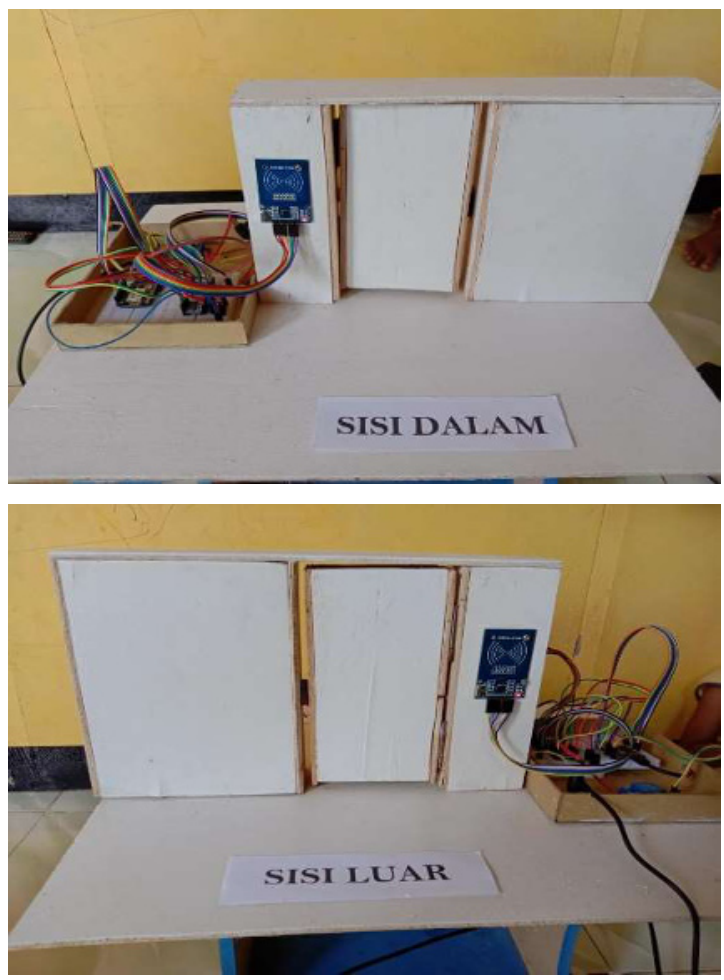

Fig. 5. Inside and Outside View of the Door

In terms of monitoring the reading data from RFID, a website is also designed by implementing programming languages such as JavaScript and PHP. The website that was built serves as a media for managing employee data as well as a media for monitoring employee mobility during working hours. In accordance with step (e) in the system architecture, the employee attendance data recording can be monitored on the website as shown in Figure 6.
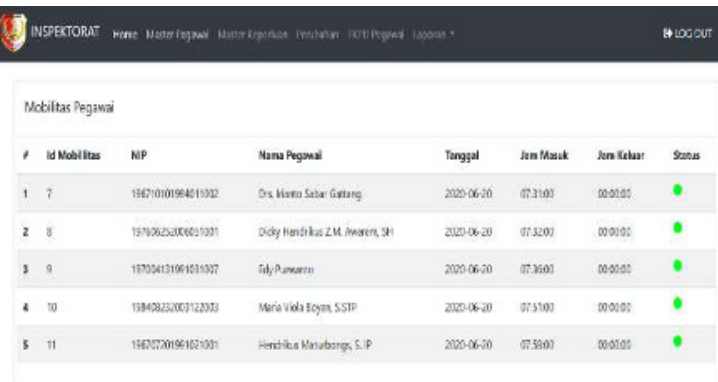

Fig. 6. Employee Mobility Monitoring Menu

Especially for the Office of General Administration and Finance, an interface is also provided to calculate the percentage of TKPD employees. The Employee TKPD menu functions as the admin menu control for the calculation of the acquisition of active working hours as well as the TKPD of employees per day. The menu form display can be seen in Figure 7.

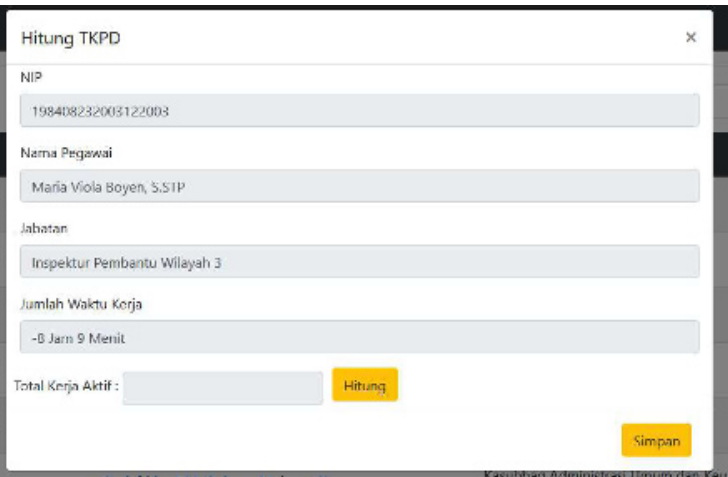

Fig. 7. TKPD Calculation Menu

\subsection{Discussion}

To ensure that the equipment is working properly, especially in the TKPD calculation section, tests are carried out based on working time at the office. The following is a system test scenario for recording and providing information based on a predetermined time as in Table 2.

\section{Conclusion}

After conducting research and testing, it can be concluded that the design of employee mobility prototypes is able to identify and provide certainty of information related to employee attendance during active working hours. In addition, the system can also calculate the percentage of employee working time per day which refers to the standard of Tunjangan Khusus Pengawasan Daerah (TKPD). So that the reporting of employee working time by the General Administration and Finance Section to office leaders can be based on the results of the system recording. 
Tabel 2. Testing Prototype Reading Results

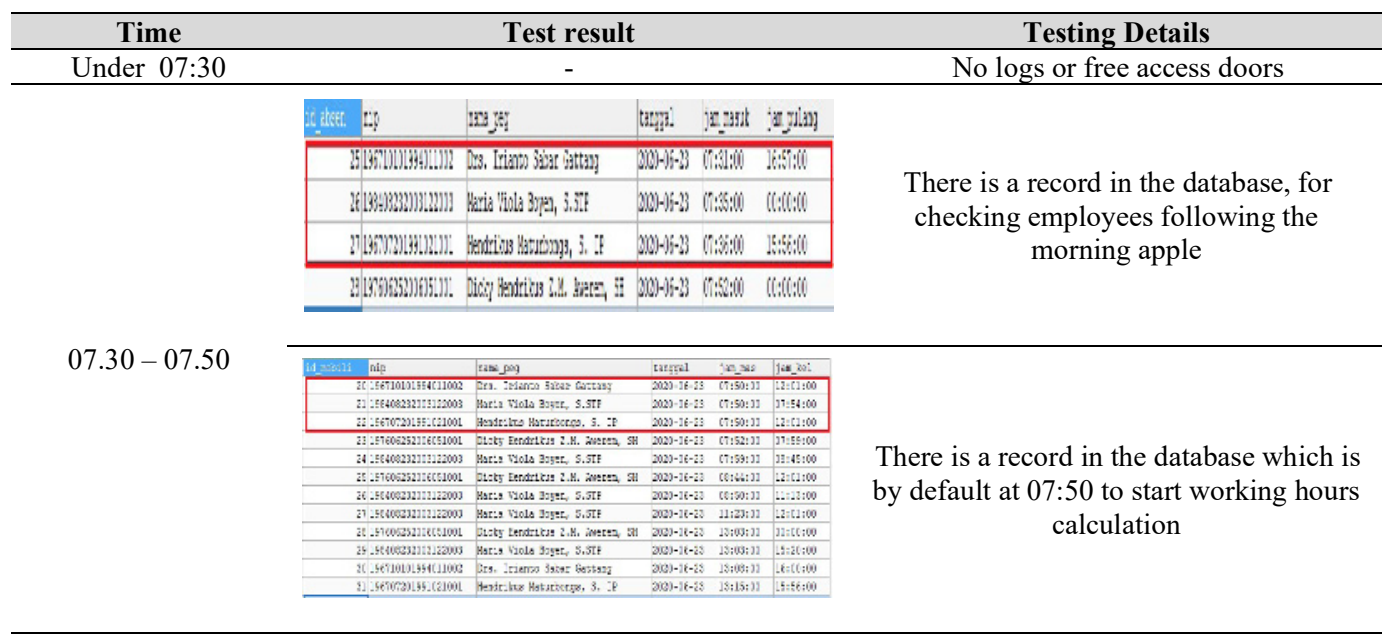

\begin{tabular}{|c|c|c|c|c|c|}
\hline $07: 50-15: 45$ & 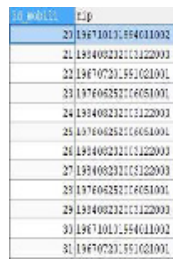 & 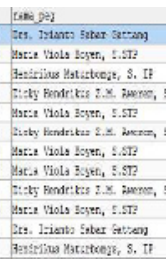 & 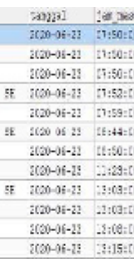 & 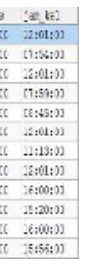 & $\begin{array}{l}\text { There is a record of mobility during } \\
\text { active working hours }\end{array}$ \\
\hline \multirow{5}{*}{$15: 46-16: 00$} & ates 4 & ing & ramal jaysth & IIFG & \multirow{5}{*}{$\begin{array}{l}\text { There is a record in the database, for the } \\
\text { condition of the acquisition of } 25 \% \text { of the } \\
\text { afternoon apples }\end{array}$} \\
\hline & 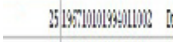 & 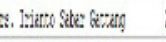 & 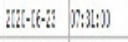 & bision:ili & \\
\hline & 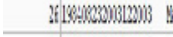 & 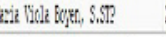 & 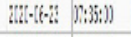 & mi:0in & \\
\hline & 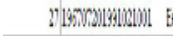 & 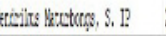 & 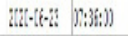 & L5:5i:i) & \\
\hline & 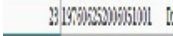 & 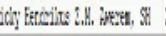 & 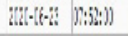 & [a:iaii) & \\
\hline
\end{tabular}

\begin{tabular}{|c|c|c|c|c|}
\hline \multirow[b]{2}{*}{ More than 16:00 } & \multicolumn{3}{|c|}{ - } & Outer Door: \\
\hline & 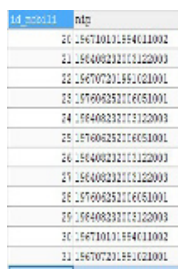 & 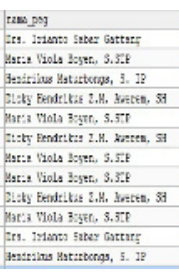 & 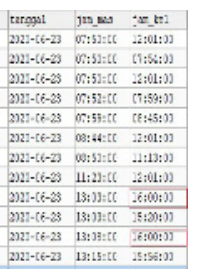 & $\begin{array}{l}\text { Inner Door: } \\
\text { There is recording, the default time out } \\
\text { automatically becomes 16:00 }\end{array}$ \\
\hline
\end{tabular}

\section{References}

1. W. Kurniawati and P. Lestari, "MOBILITAS SOSIAL NELAYAN DI KAWASAN PARIWISATA PANTAI ( Studi Kasus Pada Masyarakat Nelayan Di Pantai Depok, Desa Parangtritis , Kabupaten Bantul )," J. Pendidik. Sosiol., (2016).

2. W. Adam and L. Sagala, "Sistem Absensi Pegawai Menggunakan Teknologi RFID,” J. LPKIA, (2013).

3. G. J. Maulany and N. P. Putra, "Classification Of The Latest Handphone Products In The Toko
Rejeki Celular In Merauke District," Int. J. Mech. Eng. Technol., vol. 10, no. 1, pp. 344-351, (2019).

4. Y. Duroc and S. Tedjini, "RFID: A key technology for Humanity," Comptes Rendus Physique. (2018).

5. H. Ouldzira, A. Mouhsen, H. Lagraini, M. Chhiba, A. Tabyaoui, and S. Amrane, "Remote monitoring of an object using a wireless sensor network based on NODEMCU ESP8266," Indones. J. Electr. Eng. Comput. Sci., (2019).

6. "Rancang Bangun Magnetic Door Lock Menggunakan Keypad dan Solenoid Berbasis Mikrokontroler Arduino Uno," ELECTRANS, (2013). 
7. Dio Lavarino: Wiyli Yustanti, "Rancang Bangun E-Voting Berbasis Website Di Universitas Negeri Surabaya," J. Manaj. Inform., (2016).

8. A. Prasetio, "Buku Sakti Webmaster," Sistem Informasi Penjualan Online Pada Toko Kreatif Suncom Pacitan. (2014).

9. R. Arora and N. Arora, "Analysis of SDLC Models," Int. J. Curr. Eng. Technol., (2016).

10. Tutorialspoint, "SDLC Software Prototype Model," Tutorialspoint, (2017). 